Nimmo-Smith, R. H. \& Appleyard, G. (1956). J. gen. Microbiol. 14, 336-350

\title{
Studies with a Pseudomonad able to Grow with Greatine as Main Source of Carbon and Nitrogen
}

\author{
By R. H. NIMMO-SMITH* AND G. APPLEYARD \\ Microbiology Unit, Department of Biochemistry, \\ University of Oxford
}

SUMMARY: An organism able to grow in a simple medium with creatine as the main $\mathbf{C}$ and $\mathbf{N}$ source was isolated from garden soil and subsequently identified as Pseudomonas ovalis Chester. Organisms harvested from a creatine-containing medium destroyed creatine with the uptake of $\mathrm{O}_{2}$ and the formation of $\mathrm{CO}_{2}, \mathrm{NH}_{3}$ and urea. With the exception of urea the quantities of reactants fell short of those required by theory, and only part of the deficiency could be attributed to oxidative assimilation. Optimal conditions for the growth of active organisms and for the destruction of creatine were determined. In these conditions the organisms destroyed, in addition to creatine, only arginine and agmatine from a variety of compounds tested; compounds not attacked included creatinine and glycocyamine. Ability to oxidize creatine was partially lost during repeated washing and storage of the organisms, and was inhibited by $p$-chloromercuribenzoic acid and fatty acids.

Micro-organisms able to use creatine as a substrate for growth have been known for many years (den Dooren de Jong, 1926; Twort \& Mellanby, 1912). The classical work of Dubos and Miller revealed further species adaptively capable of destroying creatine (as well as creatinine and other substrates) in washed suspension (Miller \& Dubos, 1936; Dubos \& Miller, 1937, 1938). The use of a washed suspension of one of these species allowed a discrimination to be made between creatinine and other Jaffe-positive material in human blood. More recently organisms which can similarly use for growth creatine or creatinine as sole source of carbon and nitrogen, and which can as suspensions of the organisms degrade these two compounds, have been isolated from a number of sources (Beard, 1943, 1944; Kopper \& Beard, 1947; Roche, Girard, Lacombe \& Mourgue, 1948).

In 1949 it became apparent to workers in this Department that the use of an enzyme system specifically capable of destroying creatine would materially aid in investigations on the excretion of this compound. Unfortunately, none of the organisms mentioned above possesses the necessary degree of specificity. All appear to destroy creatinine, and some also to degrade guanidine compounds which give a colour in the method (Ennor \& Stocken, 1948) used for creatine estimation. It was decided, therefore, to attempt to isolate a micro-organism, washed suspensions of which could destroy creatine only. In this paper are reported some of the properties of a pseudomonad isolated by specific enrichment; a preliminary account of it has already been given (Nimmo-Smith, 1949).

* Present address: Wellcome Laboratories of Tropical Medicine, 183 Euston Road, London, N.W. 1. 


\section{METHODS}

Organism. The organism (whose isolation is described in Results) was maintained by monthly transfer on tryptic-casein agar slopes incubated for $24 \mathrm{hr}$. at $30^{\circ}$. It was provisionally identified as Pseudomonas eisenbergii ( $P$. non-liquefaciens), but a more thorough examination by Dr S. T. Cowan leads him to think that it is a strain of the related species $\boldsymbol{P}$. ovalis Chester. A culture has been deposited as no. 7914 in the National Collection of Type Cultures.

Medium. The basal medium used throughout contained: $\mathrm{KH}_{2} \mathrm{PO}_{4}, \mathbf{1} \cdot \mathbf{9} \mathrm{g}$.; $\mathrm{Na}_{2} \mathrm{HPO}_{4} \cdot 12 \mathrm{H}_{2} \mathrm{O}, 9 \cdot 3$ g.; NaCl, 5 g.; $\mathrm{CaCl}_{2} \cdot 6 \mathrm{H}_{2} \mathrm{O}, 100 \mathrm{mg}$.; $\mathrm{MnSO}_{4} \cdot 4 \mathrm{H}_{2} \mathrm{O}$, $10 \mathrm{mg}$.; $\mathrm{MgSO}_{4} \cdot 7 \mathrm{H}_{2} \mathrm{O}, 200 \mathrm{mg}$.; $\mathrm{FeSO}_{4} \cdot 6 \mathrm{H}_{2} \mathrm{O}, 10 \mathrm{mg}$.; yeast extract (Difco), $0.5 \mathrm{~g}$.; distilled water to $1 \mathrm{l}$; $\mathrm{pH} \mathrm{7.0.} \mathrm{To} \mathrm{this} \mathrm{basal} \mathrm{medium} \mathrm{was} \mathrm{added} \mathrm{the}$ desired growth substrate (creatine, arginine, etc.) at 2.5-5.0 g./l.

Growth experiments. The above medium (or indicated modifications of it) was distributed (for $5 \mathrm{ml}$. final volume) in $50 \mathrm{ml}$. Erlenmeyer flasks. After autoclaving for $7 \mathrm{~min}$. at $10 \mathrm{lb}$./sq.in. each flask was inoculated with $0.5 \mathrm{ml}$. of a 1/100 dilution of a $24 \mathrm{hr}$. culture in the basal medium + creatine. When a non-adapted inoculum was wanted about the same number of organisms from a tryptic casein agar slope culture were used. All incubations were at $30^{\circ}$. Inability to grow in any particular set of conditions was not concluded until after at least $\mathbf{7 2} \mathbf{~ h r}$. In later experiments, medium (final volume $\mathbf{4 . 0} \mathrm{ml}$.) was incubated in sloped $6 \times \frac{3}{4}$ in. test-tubes and growth was assessed with a photoelectric colorimeter (Evans Electroselenium Ltd.; EEL.) with a neutral density filter.

Preparation of suspensions of organisms. The medium (100 ml.) containing $0.5 \mathrm{~g}$. creatine or other substances stated, was distributed in Roux bottles and autoclaved for $7 \mathrm{~min}$. at $10 \mathrm{lb}$./sq.in. Each bottle was inoculated with $0.1 \mathrm{ml}$. of a culture of the organism in the same medium and incubated in the horizontal position at $30^{\circ}$. After $20-24 \mathrm{hr}$. the organisms were harvested on the centrifuge, washed with $0.02 \mathrm{M}$-phosphate buffer $\mathrm{pH} 7(50 \mathrm{ml}$.) and finally suspended in $5 \mathrm{ml}$. buffer or water to give a concentration of $c .5 \mathrm{mg}$. dry wt. organisms $/ \mathrm{ml}$. The relationship between dry weight and instrument reading of either the EEL. or the Hilger Spekker photoelectric colorimeter was established. A reading on the EEL. instrument of $\mathbf{2 3 . 5}$ corresponded to a suspension of $0.5 \mathrm{mg}$. dry wt. organisms $/ \mathrm{ml}$. Suspensions prepared in this way were often used at once, but could be stored at $+2^{\circ}$ for at least a week in semi-anaerobic conditions with only slight loss of activity.

Activity of suspensions. Two main methods were used to explore the specificity of the harvested organisms and to characterize the process by which creatine was destroyed.

(1) One of the objects of this work was to isolate an organism which could destroy creatine but not other compounds which give a colour with diacetyl and $\alpha$-naphthol in alkaline medium (Voges \& Proskauer, 1898; Barritt, 1936). In all the earlier experiments, therefore, organisms were shaken with a known concentration of each compound to be tested, and the amount removed 
determined colorimetrically. Once they had been established, the conditions optimal for creatine removal were used in the specificity tests. Thus a volume of $4.0 \mathrm{ml}$., containing $0.5-2.0 \mathrm{mg}$. dry wt. organisms, $1.0 \mathrm{mg}$. creatine or an equivalent weight of one of the other substrates, and buffered at $\mathrm{pH} 7 \cdot 8$ with

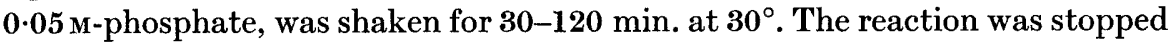
by adding $6 \cdot 0 \mathrm{ml}$. of a solution of $p$-chloromercuribenzoic acid $(0 \cdot 67 \mathrm{~g} . / 1$.$) .$

The organisms were removed by centrifuging and the amount of substrate which remained in the supernatant was estimated by the method of Eggleton, Elsden \& Gough (1943), as modified by Ennor \& Stocken (1948). For each compound tested the rate of colour-production and the relationship between concentration and colour intensity were established. The colour produced by creatine and by dimethylguanidine was measured $20 \mathrm{~min}$. after the addition of reagent; the colour produced by all other compounds was read at $40 \mathrm{~min}$. Creatinine was estimated by the Jaffe reaction.

(2) In the second method the conventional Warburg manometric technique was used, both to confirm some of the findings in the specificity tests and also to study more closely the kinetics and products of creatine catabolism. Usually, $1.0 \mathrm{ml}$. suspension (equivalent to $c .5 \mathrm{mg}$. dry wt. organisms) and $1.0 \mathrm{ml} .0 \cdot 2 \mathrm{M}$-phosphate buffer, $\mathrm{pH} 7 \cdot 8$, were placed in the main compartment of the flask and $0.5 \mathrm{ml} .0 .033 \mathrm{M}$-creatine tipped in from the side-bulb after equilibration at $30^{\circ}$. When ammonia was to be estimated the reaction mixture

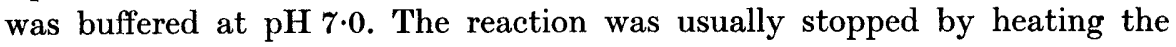
contents of the flasks for $5 \mathrm{~min}$. in a boiling water-bath; after centrifuging the supernatant fluid was used for analysis.

Creatine was estimated as above. It was found (D. D. Woods, unpublished observations) that ammonia could be estimated in the presence of urea by distilling in the Markham (1942) apparatus after the addition of $0.35 \mathrm{M}$-borate buffer of $\mathrm{pH} 8 \cdot 5$. Urea was determined by the difference in ammonia content of the solution before and after incubation with urease.

Chemicals. Some of the compounds listed in Table 5 were gifts generously made. We are indebted to Imperial Chemical Industries (through the courtesy of Dr F. L. Rose) for compounds 2 to 8, to Dr H. King for compounds 9 to 12 and 15 to 17 , and to Dr P. C. Spensley for compound 13. We are grateful also to $\mathrm{Dr} \mathrm{L}$. A. Stocken for a generous supply of $p$-chloromercuribenzoic acid. The other materials used were of commercial origin and, with two exceptions, were not further purified. Creatine was recrystallized according to Hunter (1928), and the sample of decamethylenediguanidine was converted from the carbonate to the hydrochloride.

\section{RESULTS}

\section{Isolation of the organisms}

The medium originally used was similar to that described above, but without yeast extract and containing $0.5 \%(\mathrm{w} / \mathrm{v})$ creatine; it was buffered to $\mathrm{pH} 6,7$ or 8 . Samples $(25 \mathrm{ml}$.) in $250 \mathrm{ml}$. Erlenmeyer flasks were inoculated with $c .1 \mathrm{~g}$. garden soil from several sources, and incubated at 18, 25, 30 and $37^{\circ}$. After 
incubation for 3 days diffuse microbial growth was seen in those flasks which had been inoculated from ground recently used as a chicken-run. Growth was heaviest at 25 and $30^{\circ}$, but seemed to be unaffected by the $\mathrm{pH}$ range covered. Morphological appearance and the production of a greenish yellow pigment with an electric-blue fluorescence in ultraviolet light suggested that it was the same organism growing in each flask. The culture obtained at $30^{\circ}$ and $\mathrm{pH} 7$ was subcultured five times in these conditions, with 2 days of incubation on each occasion. The fifth subculture was plated on the creatine-containing medium solidified with $1.5 \%(\mathrm{w} / \mathrm{v})$ agar, and single colonies isolated. Tested on a variety of media the organism behaved as though in pure culture and was considered to be in a state suitable for further investigation.

As stated above, the organism is probably a strain of Pseudomonas ovalis Chester. It was isolated only from soil taken from this one situation; even after 14 days of incubation flasks inoculated with soil from other sources showed no visible growth.

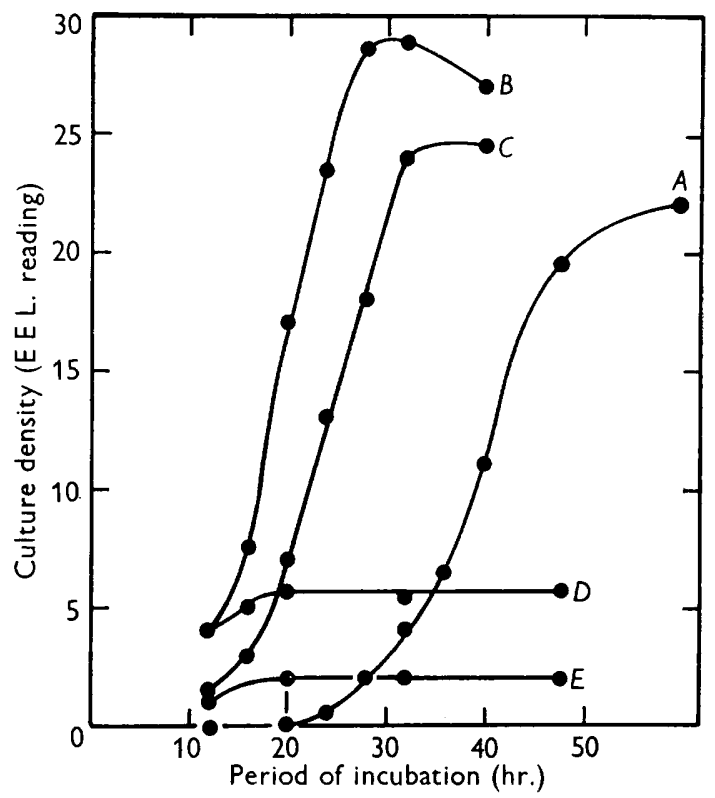

Fig. 1. Effect of yeast extract and of casein hydrolysate on growth of Pseudomonas ovalis. Basal medium supplemented with $5 \mathrm{mg} . / \mathrm{ml}$. creatine $(A)$, creatine $+0.5 \mathrm{mg} . / \mathrm{ml}$. Difco yeast extract $(B)$, creatine $+0.1 \mathrm{mg} . / \mathrm{ml}$. acid-hydrolysed casein $(C)$, yeast extract alone $(D)$ or acid-hydrolysed casein alone $(E)$. Incubation at $30^{\circ}$ in sloped test-tubes.

\section{Some growth properties of the organism}

The organism grew very well on all the common laboratory media tested, but only under aerobic conditions.

Effect of yeast extract. In the simple medium with creatine as only added organic constituent growth was less rapid than in more complex media. Inclusion of $0.05 \%(\mathrm{w} / \mathrm{v})$ yeast extract decreased the lag period and somewhat increased the rate and extent of growth (Fig. 1). Yeast extract was normally 
included in the medium used for growth tests and always when the cultures were to prepare suspensions of organisms.

An attempt was made to discover what component of the yeast extract was responsible for its stimulatory effect. Several vitamins were tested, singly or in groups, at various concentrations. Neither biotin, pyridoxin, pyridoxal, nicotinic acid, pantothenic acid, riboflavin, thiamine nor $p$-aminobenzoic acid improved growth. Acid-hydrolysed casein caused a similar marked decrease in the lag period (Fig. 1) which could not be traced to the effect of any particular amino acid. The single addition of almost any amino acid has some effect; glutamic acid (and glutamine), aspartic acid, histidine, proline, and hydroxyproline were the most active. Both yeast extract and acid-hydrolysed casein also improved growth on the basal medium containing glucose and ammonium salts (quantities as in Table 1) in place of creatine. In the presence of yeast extract the further addition of either glucose or of ammonium salt to the creatine medium led to a considerable increase in total growth (Table 4).

$\mathrm{pH}$ range. Growth of the organism was remarkably independent of hydrogenion concentration, and was almost equally good between $\mathrm{pH}$ values of $5 \cdot 4$ and 9.0 with an ill-defined optimum in the region of $\mathrm{pH} 8 ; \mathrm{pH} \mathrm{7.0} \mathrm{(which} \mathrm{was} \mathrm{also}$ about the optimum for creatine destruction) was chosen for all subsequent work.

The importance of other ions was also investigated briefly. A fairly high concentration of $\mathrm{NaCl}$ was found to be obligatory; below $0.1 \%(\mathrm{w} / \mathrm{v})$ growth was suboptimal, and above $2 \%$ the salt was inhibitory. Traces of $\mathrm{Ca}, \mathrm{Mg}, \mathrm{Mn}$ and $\mathrm{Fe}$ were essential.

Temperature. A temperature of $30^{\circ}$ was near the optimum for growth. Incubation at $25^{\circ}$ resulted in a slight decrease; raising the temperature to $37^{\circ}$ decreased growth at $24 \mathrm{hr}$. to about one-half of that at $30^{\circ}$.

Aeration. Roux bottles incubated horizontally provided the largest crops. Growth after $24 \mathrm{hr}$. was decreased considerably when the bottles were kept in the vertical position, or even when they were sloped so as to present half the normal surface area to the atmosphere.

An attempt was made to increase the crop by cultivating in medium continuously agitated by a magnetic stirrer. Although this procedure must have resulted in increased aeration, growth after $24 \mathrm{hr}$. was only one-third of that in undisturbed Roux bottles. A similar decrease was observed in Roux bottles which were shaken by hand every few hours. To test whether a raised oxygen tension might be inhibitory, a Roux bottle was filled with oxygen after inoculation; growth at $\mathbf{2 4} \mathrm{hr}$., however, was as good as in a bottle exposed to air in the usual way.

Substrates for growth. In testing the ability of the organism to use a variety of single substances for growth these were added to the basal medium without yeast extract to give a concentration of $0 \cdot 3 \%(w / v)$; when pairs of substances were tested each was present at $\mathbf{0 . 2 5} \%$. Failure to grow was recorded when no visible growth occurred after 3 to 4 days. A number of nitrogenous organic compounds were tested for their ability to support growth (Table 1); nonnitrogenous organic compounds were tested in the presence of ammonium 
salts. Of most interest was the limited ability to grow on guanidine derivatives; of those tested only creatine, arginine and the amine of arginine, agmatine, supported full growth. There was a limited ability to use guanidine itself, but none to use creatinine or glycocyamine. Urea was used as a nitrogen source (in the presence of glucose as a carbon source), and sarcosine as source of both nitrogen and carbon.

\section{Table 1. Substances tested for their ability to support growth of Pseudomonas ovalis Chester as source of $\mathrm{C}$ and $\mathrm{N}$}

Single compounds at $0.3 \%(\mathrm{w} / \mathrm{v})$ in the basal medium; $\mathrm{NH}_{4}^{+}$salt and carbon source at $0.25 \%$ each. $0=$ no growth up to 5 days; $++++=$ abundant growth, etc.

(a) Guanidine derivatives

$\begin{array}{lrlr}\text { Creatine } & ++++ & \text { Methylguanidine } & 0 \\ \text { Creatinine } & 0 & \text { Dimethylguanidine } & 0 \\ \text { Glycocyamine } & 0 & \text { Ethylguanidine } & 0 \\ \text { Arginine } & +++ & \text { Tetramethylenediguanidine } & 0 \\ \text { Agmatine } & ++++ & \text { Decamethylenediguanidine } & 0 \\ \text { Guanidine } & + & & \end{array}$

(b) Possible primary breakdown products of creatine

$\begin{array}{lrrr}\text { Sarcosine } & ++++ & \text { Urea }+ \text { glycine } & 0 \\ \text { Glycine } & 0 & \text { Urea }+ \text { glucose } & ++++ \\ \text { Urea } & 0 & \end{array}$

(c) Amino acids and miscellaneous compounds

Alanine
Serine
Aspartate
Glutamate
Methionine
Tryptophan

$\begin{array}{ll} \pm & \text { Asparagine } \\ \pm & \mathrm{NH}_{4}+\text { glucose } \\ 0 & \mathrm{NH}_{4}+\text { acetate } \\ 0 & \mathrm{NH}_{4}+\text { citrate } \\ 0 & \text { Choline } \\ 0 & \text { Indole }\end{array}$$$
\begin{array}{r}
+ \\
+++ \\
++ \\
+ \\
++ \\
0
\end{array}
$$

\section{Action of suspensions on creatine}

When suspensions of organisms harvested from the creatine medium were incubated aerobically with creatine, the substrate disappeared at a uniform rate until all had been removed (Fig. 2). Organisms destroyed their own (dry) weight in 1-2 hr.

The disappearance of creatine was accompanied by uptake of $\mathrm{O}_{2}$ and by formation of $\mathrm{CO}_{2}, \mathrm{NH}_{3}$ and urea. In the absence of any added substrate suspensions of organisms had a $Q_{\mathrm{O}_{2}}$ of 20-30; this endogenous uptake was always subtracted from the values observed in the presence of substrate to give the recorded values. In the presence of creatine the corrected $Q_{\mathrm{O}_{2}}$ was about 100 and $\mathrm{O}_{2}$ uptake continued at a regular rate during the removal of creatine. At, or slightly after, the time when the creatine had completely disappeared the rate of $\mathrm{O}_{2}$ consumption abruptly fell to a much lower level. Yet even when incubation was continued for many hours after the 'break' in the curve, the rate of $\mathrm{O}_{2}$ consumption never fell quite to the value without substrate (Fig. 2).

At the time of the 'break' in the $\mathrm{O}_{2}$ uptake curve about 1.4 mole $\mathrm{O}_{2} /$ mole creatine (limits $1 \cdot 3-1.5$ mole) were taken up. Production of $\mathrm{CO}_{2}$ followed a 
course very similar to that of $\mathrm{O}_{2}$ uptake (Fig. 2). At the 'break' about 1.5 mole $\mathrm{CO}_{2} /$ mole creatine were formed.

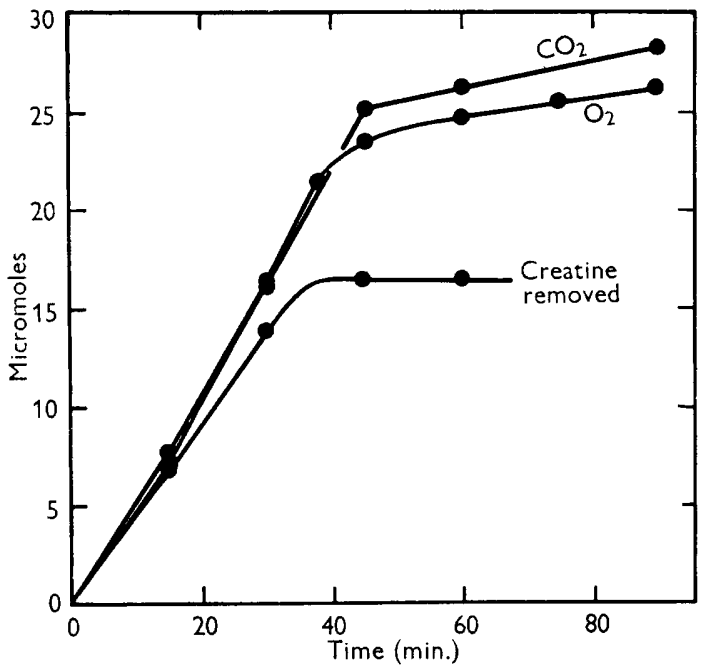

Fig. 2. Uptake of $\mathrm{O}_{2}$ and evolution of $\mathrm{CO}_{2}$ in relation to creatine disappearance. Organisms (equiv. to $5 \mathrm{mg}$. dry wt.) in $0.08 \mathrm{M}$-phosphate buffer ( $\mathrm{pH} 7 \cdot 8$ ) with 16.7 $\mu$ mole creatine; total volume $2 \cdot 5 \mathrm{ml}$. Incubated at $30^{\circ}$ in air.

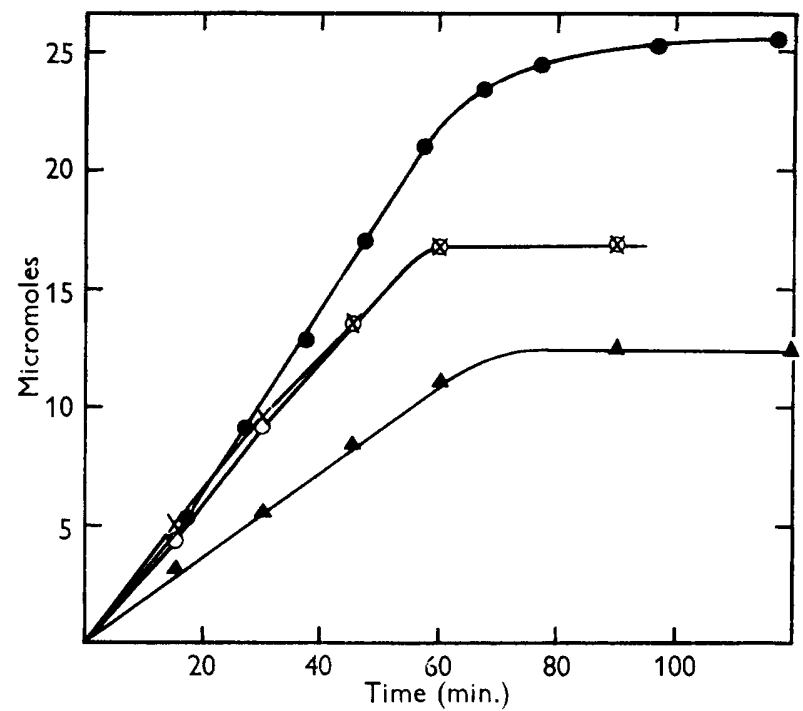

Fig. 3. Creatine removal $(x), \mathrm{O}_{2}$ uptake (O), urea (O) and $\mathrm{NH}_{3}(\Delta)$ formation by suspensions of Pseudomonas ovalis. Organisms $6 \mathrm{mg}$. (dry wt.); other additions as in Fig. 2.

About 0.7 mole $\mathrm{NH}_{3}$ (limits 0.65-0.75) was formed (Fig. 3). On two occasions ammonia was estimated as volatile base in the Markham apparatus and by its colour production with Nessler's reagent. At the concentrations used 
methylamine, a possible product of creatine breakdown, behaved as ammonia on steam distillation but gave no colour with Nessler's reagent. Since the values given by the two methods were in excellent agreement it was concluded that no methylamine was being produced. At all stages of the reaction 1 mole urea/mole creatine was formed (Fig. 3).

Amino acids were sought by paper partition chromatography, fatty acids by distillation with phosphoric acid in the Markham apparatus, and formaldehyde by its colour reaction with chromotropic acid. None of these compounds was detected in the reaction mixture.

Oxidative assimilation. The degradation of creatine to $\mathrm{CO}_{2}$, ammonia and urea required in theory the appearance of 3 mole $\mathrm{CO}_{2}$ and one each of the other two products, together with the uptake of 3 mole $\mathrm{O}_{2}$. The considerable discrepancies between the observed values (with the exception of urea) and the theoretical suggested either that there were undetected products or that some of the creatine might be undergoing oxidative assimilation (Clifton, 1946). To test the latter possibility organisms were incubated with creatine in the presence of sodium azide or 2:4-dinitrophenol. Different batches of organisms varied considerably in their sensitivity to azide and the optimal concentration varied by as much as a factor of three from one suspension to another. In the presence of that concentration of azide $\left(c .10^{-3} \mathrm{M}\right)$ which had the most marked effect the $\mathrm{O}_{2}$ consumption at the 'break' was increased only by a factor of about 1.2 (Table 2); there was a similar proportionate increase in $\mathrm{CO}_{2}$ and $\mathrm{NH}_{3}$ production. It is clear that it is not possible to account for the missing creatine by oxidative assimilation unless this is considerably greater than it was possible to demonstrate.

\section{Table 2. Effect of azide on the oxidation of creatine} by Pseudomonas ovalis Chester

Organisms (equiv. to $4 \mathrm{mg}$. dry wt.) were incubated in $0.067 \mathrm{M}$-phosphate buffer (pH 7 ) with $16.7 \mu$ mole creatine in presence or absence of sodium azide $(2 \mu \mathrm{mole})$; total volume $3 \mathrm{ml}$. The reaction was stopped after $100 \mathrm{~min}$.; the 'break' in $\mathrm{O}_{2}$ uptake occurred after $60 \mathrm{~min}$. in absence of azide and after $90 \mathrm{~min}$. in its presence. All creatine had been removed in both cases.

\begin{tabular}{lccc} 
& \multicolumn{3}{c}{ Moles/mole creatine removed } \\
\cline { 2 - 4 } $\mathrm{O}_{2}$ taken up & $\mathbf{A z i d e}$ absent & Azide present & Theory* \\
$\mathrm{CO}_{2}$ formed & 1.74 & 1.95 & 3.0 \\
$\mathrm{NH}_{2}$ formed & 0.70 & 2.01 & 3.0 \\
Urea formed & 0.99 & 0.81 & 1.0 \\
& & 1.01 & 1.0
\end{tabular}

* For complete oxidation according to

$$
\mathrm{NH}_{2} \cdot \mathrm{C}(=\mathrm{NH}) \cdot \mathrm{N}\left(\mathrm{CH}_{3}\right) \cdot \mathrm{CH}_{2} \cdot \mathrm{COOH}+3 \mathrm{O}_{2}=\mathrm{CO}\left(\mathrm{NH}_{2}\right)_{2}+\mathrm{NH}_{3}+3 \mathrm{CO}_{2}+\mathrm{H}_{2} \mathrm{O} \text {. }
$$

Several attempts were made to confirm this 'uncoupling' effect with dinitrophenol. On only one occasion was the $\mathrm{O}_{2}$ uptake increased (to $2 \cdot 0$ mole); at all other times dinitrophenol was without effect. 


\section{Kinetics of creatine destruction}

Concentration of organisms. Below a concentration of c. $3 \mathrm{mg}$. dry wt. organisms $/ \mathrm{ml}$. the rate of creatine removal and $\mathrm{O}_{2}$ uptake was directly proportional to the concentration of organisms. Above this concentration $\mathrm{O}_{2}$ consumption increased only slowly and was never more than $1000 \mu \mathrm{l}$./hr. At high suspension densities the factor limiting rate of $\mathrm{O}_{2}$ uptake appeared to be the rate at which $\mathrm{O}_{2}$ diffused into the reaction mixture or into the organisms. When the flasks were filled with $\mathrm{O}_{2}$ instead of with air a far greater rate of uptake was attained (Fig. 4).

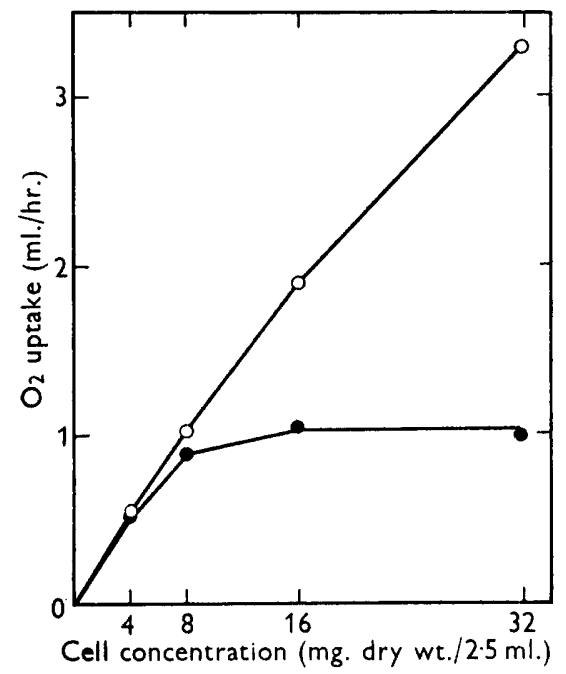

Fig. 4

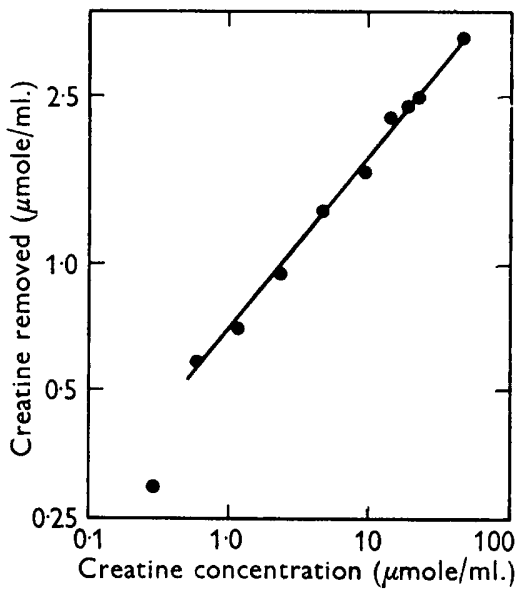

Fig. 5

Fig. 4. Effect of $\mathrm{O}_{2}$ tension on activity of suspensions of Pseudomonas ovalis. Organisms (different concentrations) with other additions as in Fig. 2. Shaken at $30^{\circ}$ in air $(\odot)$ or $\mathrm{O}_{2}(\mathrm{O})$. Not corrected for endogenous $\mathrm{O}_{2}$ uptake.

Fig. 5. Influence of initial creatine concentration upon rate of creatine removal by Pseudomonas ovalis. Different amounts of creatine were incubated with suspensions of organisms equivalent to $1.76 \mathrm{mg}$. dry wt. in $4 \mathrm{ml} .0 .05 \mathrm{M}$-phosphate buffer $(\mathrm{pH} 7)$ for 50 min. at $30^{\circ}$.

Creatine concentration. Oxygen uptake reached a maximum rate when the creatine concentration was about $10^{-2} \mathrm{M}$. The rate of creatine disappearance, however, continued to increase up to at least $4 \cdot 7 \times 10^{-2} \mathrm{M}$, the highest concentration tested. Over almost a 100-fold range of concentration there was a linear relationship between the logarithm of the initial creatine concentration and the logarithm of its rate of destruction (Fig. 5).

$\mathrm{pH}$ range. The optimum $\mathrm{pH}$ for destruction of creatine in $0.05 \mathrm{M}$-phosphate buffer was in the region of 8.0. There was no sharp peak in the pH-activity curve (Fig. 6). In spite of the slightly decreased activity in the presence of $0.05 \mathrm{M}$-borate a much better-defined optimum than with phosphate was found at pH 8.25 (Fig. 6). Where comparison could be made the rate of creatine 
removal was even less in the presence of veronal; for instance at $\mathrm{pH} \mathbf{7 \cdot 8}$ the rate was one-third of the rate in phosphate. As the $\mathrm{pH}$ value was increased to the end of the veronal range (about $\mathrm{pH} 9 \cdot 4$ ) the rate rose steadily to $70 \%$ of that at the phosphate optimum.

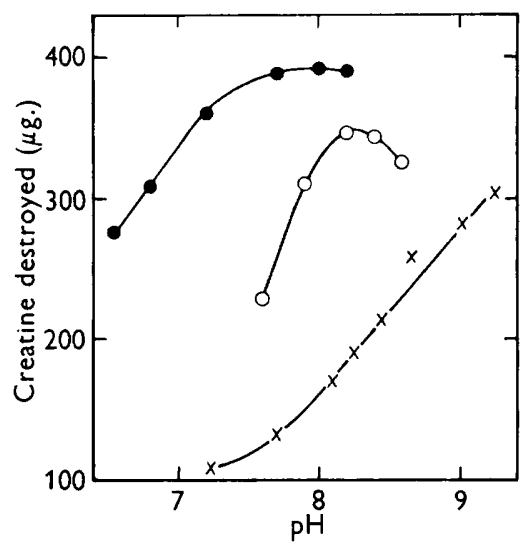

Fig. 6

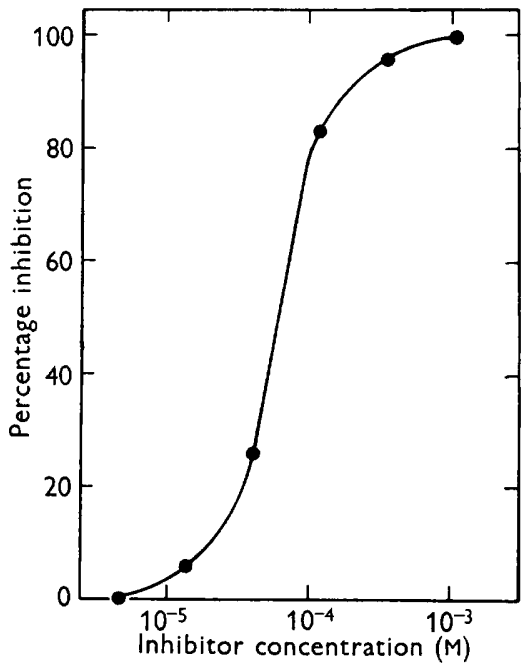

Fig. 7

Fig. 6. Effect of $\mathrm{pH}$ and of nature of buffer on creatine destruction of Pseudomonas ovalis. Four ml. of $0.05 \mathrm{M}$-phosphate $(\odot)$, borate $(O)$, or veronal $(x)$ buffer containing the equivalent of $1.08 \mathrm{mg}$. dry wt. organisms and $1.0 \mathrm{mg}$. creatine; incubated at $30^{\circ}$ for 45 min.

Fig. 7. Inhibition by $p$-chloromercuribenzoate of creatine removal by Pseudomonas ovalis. Organisms (equivalent to $1.35 \mathrm{mg}$. dry wt.) in $4 \mathrm{ml}$. $0.05 \mathrm{~m}$-phosphate buffer (pH 7) with $1.0 \mathrm{mg}$. creatine; incubated $1 \mathrm{hr}$. at $30^{\circ}$.

Inhibitors. $p$-Chloromercuribenzoic acid (as the sodium salt) completely inhibited destruction of creatine. With a suspension equivalent to $0.2 \mathrm{mg}$. dry wt. organisms $/ \mathrm{ml} .50 \%$ inhibition was induced by $6 \cdot 6 \times 10^{-5} \mathrm{M}-p$-chloromercuribenzoate (Fig. 7). In a further experiment, with a suspension of organisms ten times more concentrated, $\mathrm{O}_{2}$ uptake was inhibited $50 \%$ by a $4.5 \times 10^{-5} \mathrm{M}-p$ chloromercuribenzoate.

During investigation of the effect of $\mathrm{pH}$ value upon the reaction it was discovered that acetate caused a powerful inhibition (Fig. 8). Other fatty acids were also inhibitory, the order of decreasing activity being acetate, propionate, butyrate, formate; these tests were made at $\mathrm{pH} 6$. Creatine removal was inhibited $50 \%$ by acetate at $5 \times 10^{-3} \mathrm{M}$, propionate at $7 \times 10^{-3} \mathrm{M}$ and butyrate at $2 \times 10^{-2} \mathrm{M}$. Formate was much less effective; at $5 \times 10^{-2} \mathrm{M}$ (the highest concentration tested) it produced only $25 \%$ inhibition.

Inhibition by acetate was completely independent of creatine concentration. A concentration of acetate expected to cause about $50 \%$ inhibition was added to a series of flasks, in which the creatine concentration was varied over a 64-fold range. The degree of inhibition varied only between 50 and $65 \%$. 
Loss of activity on storage and washing. Harvested organisms lost some activity either during storage at $0^{\circ}$ (especially when exposed to air) or on further washing with phosphate buffer (Table 3). Activity was partly or wholly restored by Difco yeast extract (1 $\mathrm{mg} . / \mathrm{ml}$.) or by DL-cystine (125 $\mathrm{mg} . / \mathrm{ml}$.).

Table 3. Loss of creatine-destroying activity induced by washing Pseudomonas ovalis with phosphate buffer, and stimulation by yeast extract

Organisms (equivalent to $0.55 \mathrm{mg}$. dry wt.) were incubated for $1 \mathrm{hr}$. at $30^{\circ}$ in a volume of $4 \mathrm{ml}$. at $\mathrm{pH} 7.8$ with $1000 \mu \mathrm{g}$. creatine, with or without yeast extract $(1 \mathrm{mg} . / \mathrm{ml}$.). Organisms from normal suspensions (once washed) were centrifuged and washed repeatedly with $0.02 \mathrm{M}$-phosphate buffer $\mathrm{pH} 7$; samples were taken after each washing.

$\begin{array}{ccc}\begin{array}{c}\text { Number of } \\ \text { extra washes }\end{array} & \overbrace{\text { No yeast extract }}^{\text {Creatine removed }(\mu \mathrm{g} .)} \\ 0 & \overbrace{\text { With yeast extract }}^{\text {Suspension }} \\ 1 & 473 & 552 \\ 2 & 308 & 496 \\ 3 & 200 & 400 \\ 185 & 420\end{array}$

\section{Adaptive nature of creatine oxidation}

Only organisms grown with creatine as main carbon and nitrogen source possessed full ability immediately to remove creatine. Organisms grown with either arginine or with glucose + ammonia removed no creatine during an incubation period $(1 \mathrm{hr}$.) when creatine-grown organisms had removed the whole of the substrate. When incubation was continued beyond $1 \mathrm{hr}$. organisms grown in the absence of creatine began slowly to oxidize this compound and continued at an increasing rate (Fig. 9).

As described earlier, the addition of either glucose, or of ammonium salt, or of both, considerably increased the total amount of growth in the creatine medium. Organisms grown in this way, however, showed a loss of intrinsic activity which more than offset the increased growth (Table 4). Organisms were also grown on the usual creatine medium solidified with $3 \%(\mathrm{w} / \mathrm{v})$ agar; growth was then about $\mathbf{7 0} \%$ better than in the liquid medium, but activity/ amount of organism was decreased almost proportionately.

\section{Specificity of action of suspensions}

Organisms were grown on media containing creatine, arginine, or glucose + ammonium salt and their activity towards a number of guanidine derivatives and related compounds was tested. Some of the results of such experiments, in which the criterion of activity was the disappearance of substrate, are summarized in Table 5. Tests on the specificity of creatine-grown organisms were extended to include several further compounds which develop a colour with diacetyl and $\alpha$-naphthol in alkaline solution. None of the compounds tested was attacked (Table 6). In addition, manometric experiments showed that organisms grown in a creatine medium were unable to oxidize creatine 
Table 4. Effect upon growth of Pseudomonas ovalis and upon creatineoxidising activity of supplementing the creatine medium with ammonium salts and glucose

Cultures of $P$. ovalis were incubated in Roux bottles at $30^{\circ}$ for $24 \mathrm{hr}$.; the normal creatinecontaining medium had the supplements stated. Organisms (equivalent to 8-16 mg. dry wt.) incubated in $0.08 \mathrm{M}$-phosphate buffer $\left(\mathrm{pH} \mathrm{7.8)}\right.$ with $16.7 \mu$ mole creatine. Endogenous $\mathrm{O}_{2}$ uptake not subtracted.

Supplement to growth medium

\section{Growth} (mg. dry wt./100 ml.)

(1) Nil

(2) $\left(\mathrm{NH}_{4}\right)_{2} \mathrm{SO}_{4}, 0.25 \%(\mathrm{w} / \mathrm{v})+$ $\mathrm{NH}_{4} \mathrm{Cl}, 0 \cdot 25 \%(w / v)$

(3) Glucose, $0.5 \%(w / v)$

(4) $(2)+(3)$

$\begin{array}{rr}38 & 124 \\ 51 & 86 \\ & \\ 69 & 50 \\ 83 & 33\end{array}$

Table 5. Influence of the growth substrate upon the relative ability of suspensions of Pseudomonas ovalis to remove various substrates

Suspensions of organisms (equivalent to 1.0-1.3 mg. dry wt.) harvested from the basal medium with indicated supplements and incubated for $1 \mathrm{hr}$. with $1.0 \mathrm{mg}$. creatine or an equivalent weight of the other substrates.

Relative rate* of removal of substrate by organisms grown on

\begin{tabular}{lrrc}
\multicolumn{1}{c}{ Substrate } & Creatine & Arginine & $\mathrm{NH}_{\mathbf{4}}^{+}+$glucose \\
Creatine & 100 & 0 & 0 \\
Arginine & 10 & 100 & 0 \\
Agmatine & 30 & 50 & 0 \\
Glycocyamine & 0 & 0 & 0 \\
Creatinine & 0 & 0 & 0
\end{tabular}

* Rate of removal of creatine by creatine-grown organisms $=100$.

Table 6. Guanidino compounds not attacked by creatine-grown

Pseudomonas ovalis

(a) Monoguanidino derivatives<smiles>[R]NC(=N)N</smiles>

No.

$1-\mathbf{H}$

$2-\mathrm{CH}_{3}$

$3-\mathrm{CH}_{2}-\mathrm{CH}_{3}$

$4-\left(\mathrm{CH}_{2}\right)_{2}-\mathrm{CH}_{3}$

$5-\mathrm{CH}=\left(\mathrm{CH}_{3}\right)_{2}$

$6-\left(\mathrm{CH}_{2}\right)_{3}-\mathrm{CH}_{3}$

$7-\mathrm{CH}_{2}-\mathrm{CH}=\left(\mathrm{CH}_{3}\right)_{2}$

$8-\left(\mathrm{CH}_{2}\right)_{2}-\mathrm{N}=\left(\mathrm{C}_{2} \mathrm{H}_{5}\right)_{2}$

$9-\left(\mathrm{CH}_{2}\right)_{11}-\mathrm{CH}_{3}$

$10-\left(\mathrm{CH}_{2}\right)_{13}-\mathrm{CH}_{3}$

$11-\left(\mathrm{CH}_{2}\right)_{15}-\mathrm{CH}_{3}$

$12-\left(\mathrm{CH}_{2}\right)_{17}-\mathrm{CH}_{3}$

13 -2-benziminazole (b) Diguanidino derivatives<smiles>N=C(N)NCCCNC(=N)N</smiles>

No. $n=$

144 (arcaine)

155

166

$\begin{array}{ll}17 & 8\end{array}$

1810 (synthalin)

1912 (synthalin B) 
phosphate, dimethylguanidine, hydantoic acid or urea oxalate. Absence of $\mathrm{O}_{2}$ uptake confirmed their inability to oxidize guanidine, methylguanidine or creatinine.

When creatine-grown organisms were incubated in the usual way with glycocyamine, $\mathrm{O}_{2}$ consumption was about $50 \%$ higher than the endogenous value; i.e. there was a $Q_{\mathrm{O}_{2}}$ of about 10 apparently due to the oxidation of glycocyamine. On the other hand, colorimetric estimation showed no loss of glycocyamine, and even after $5 \mathrm{hr}$. of incubation, no urea or ammonia was detected

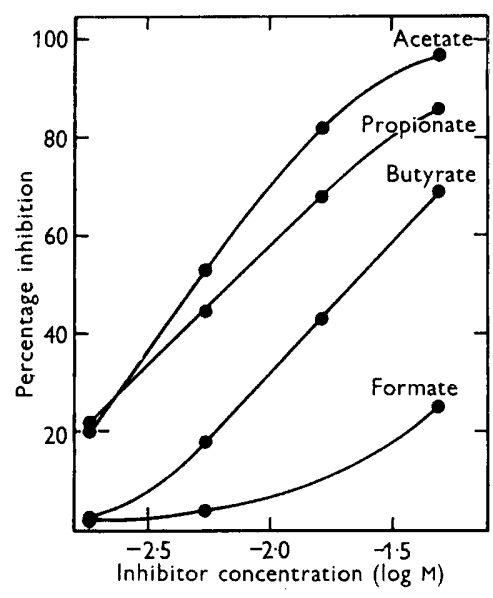

Fig. 8

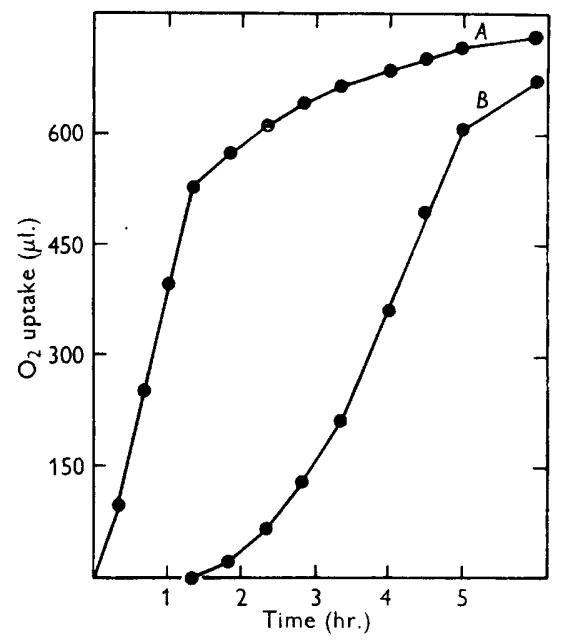

Fig. 9

Fig. 8. Inhibition by fatty acids of Pseudomonas ovalis. Organisms (equivalent to $1 \cdot 17 \mathrm{mg}$. dry wt.) incubated as in Fig. 7 except that buffer was pH 6 . Acids brought to pH 6 before addition.

Fig. 9. Effect of growth substrate upon oxidation of ereatine by suspensions of Pseudomonas ovalis. Organisms (equivalent to $4.5 \mathrm{mg}$. dry wt.) grown on medium containing creatine $(A)$ or glucose and ammonium salts $(B)$ and incubated in $0.08 \mathrm{M}$-phosphate buffer (pH 7.8) with 16.7 $\mu$ mole creatine.

in the reaction mixture. It was thought just possible that glycocyamine was being converted to guanidine (by oxidation of the acetic acid side-chain) or to some other guanidino compound giving a similar colour reaction; yet paper chromatography gave no evidence of this. It was concluded that such suspensions of organisms were unable to oxidize glycocyamine.

\section{DISCUSSION}

The micro-organism isolated in the present work appears to produce an adaptive system of enzymes which enable it to grow with creatine as main source of carbon and nitrogen. It differs from other organisms having this property in its high degree of specificity. In particular it does not attack creatinine; it is unable to grow on a medium containing creatinine as main organic constituent, 
and washed organisms do not destroy creatinine. The only other guanidine derivatives which are attacked by creatine-grown organisms are arginine and agmatine, which are destroyed relatively slowly. The mechanisms of degradation of these two compounds are probably different from that of creatine, since organisms grown on an arginine medium are unable to metabolize creatine. This degree of specificity provides the basis for a method for the selective destruction of creatine in a mixture which also contains creatinine or other guanidine derivatives. It has been exploited by Ennor \& Stocken (1953) in determining the urinary excretion of creatine.

Of the products of the reaction in which creatine was destroyed only urea was found in theoretical yield. The formation of 1 mole urea from 1 mole guanidine derivative appears to be a rather constant finding in other cases where this point has been investigated (Dubos \& Miller, 1937; Kopper \& Beard, 1947; Krebs \& Eggleston, 1939; Roche et al. 1948). An exception to this was found with arginine; Hills (1940) showed that certain Gram-positive cocci contain an enzyme, arginine dihydrolase, which hydrolyses arginine directly to ornithine, $\mathrm{NH}_{3}$ and $\mathrm{CO}_{2}$ without the intermediate formation of urea. Roche, Lacombe \& Girard (1950) studied the action on arginine of growing cultures of our strain of Pseudomonas ovalis Chester, and concluded that it also produces an arginine dihydrolase.

Further work on the reactions involved in the degradation of creatine by this organism is described in the following paper (Appleyard \& Woods, 1956).

This work was carried out during the tenure by one of us (G.A.) of a Medical Research Council Scholarship.

\section{REFERENCES}

Appleyard, G. \& Woods, D. D. (1956). The pathway of creatine catabolism by Pseudomonas ovalis Chester. J. gen. Microbiol. 14, 351.

BarritT, M. M. (1936). The intensification of the Voges-Proskauer reaction by the addition of $\alpha$-naphthol. J. Path. Bact. 42, 441.

BEARD, H. H. (1943). The production of a creatine oxidase and a creatine anhydrase from rat faeces. Arch. Biochem. 2, 363.

Beard, H. H. (1944). Production of a creatine-creatinine destroying enzyme from a urine mould. Arch. Biochem. 5, 293.

Chifton, C. E. (1946). Microbial assimilations. Advanc. Enzymol. 6, 269.

DEN Dooren DE Jong, L. E. (1926). Bijdrage tot de kennis van het mineralsatieproces. Dissertation, Rotterdam.

Dubos, R. \& Miller, B. F. (1937). The production of bacterial enzymes capable of decomposing creatinine. J. biol. Chem. 121, 429.

Dubos, R. \& Miller, B. F. (1938). A bacterial enzyme which converts creatine into its anhydride creatinine. Proc. Soc. exp. Biol., N.Y., 39, 65.

Eggleton, P., Elsden, S. R. \& Gough, N. (1943). The estimation of creatine and diacetyl. Biochem. J. 37, 526.

Ennor, A. H. \& Stocken, L. A. (1948). The estimation of creatine. Biochem. J. 42, 557.

Ennor, A. H. \& Stocken, L. A. (1953). The application of the diacetyl reaction to the estimation of creatine in urine. Biochem. J. 55, 310.

Hills, G. M. (1940). Ammonia production by pathogenic bacteria. Biochem. J. 34, 1057. 
Hunter, A. (1928). Creatine and Creatinine. London: Longmans Green and Co.

Kopper, P. H. \& BeArd, H. H. (1947). Creatinase activity of a strain of Pseudomonas. Arch. Biochem. 15, 195.

Krebs, H. A. \& Eggleston, L. V. (1939). Bacterial urea production. Metabolism of Corynebacterium ureafaciens. Enzymologia, 7, 310.

MARкнAм, R. (1942). A steam distillation apparatus suitable for micro-Kjeldahl analysis. Biochem. J. 36, 790.

Mrluer, B. F. \& Dubos, R. (1936). Enzyme for decomposition of creatinine and its action on the 'apparent creatinine' of blood. Proc. Soc. exp. Biol., N.Y., 35, 335.

Nimmo-Smith, R. H. (1949). A pseudomonad capable of growing on creatine as sole source of carbon and nitrogen. Abst. 1st Int. Congr. Biochem. p. 297.

Roche, J., Girard, H., Lacombe, G. \& Mourgue, M. (1948). Sur la dégradation de la glycocyamine par Pseudomonas ovalis. Glycocyaminase et argininedihydrolase bactériennes. Biochim. biophys. Acta, 2, 414.

Roche, J., Lacombe, G. \& Girard, H. (1950). Sur la spécificité de certaines déguanidases bactériennes génératrices d'urée et sur l'argininedihydrolase. Biochim. biophys. Acta, 6, 210.

Twort, F. W. \& Meliandey, E. (1912). On creatin-destroying bacilli in the intestine, and their isolation. $J$. Physiol. 44, 43.

Voges, O. \& Proskauer, B. (1898). Beitrag zur Ernährungsphysiologie und zur Differentialdiagnose der Bakterien der hämmorrhagischen Septicämie. Z. Hyg. InfektKr. 28, 20.

(Received 22 September 1955) 